Seventeen per cent. of cases were thought to be occupational. In the diagnosis of industrial dermatitis the course of the illness, especially in relation to changes in work, is often of decisive importance.

\section{REFERENCES}

Calnan, C. D., and Wells, G. C. (1956). Brit. med. F., 1, 1265. Gross, P. (1959). Ann. Allergy, 17, 745.
Heseltine, G. F. (1963). F. psychosom. Res., 7, 241.

Hjorth, N. (1963). Trans. St fohn's Hosp. derm. Soc. (Lond.), 49, 99.

MacKenna, R. M. B. (1961). Practitioner, 186, 737.

Sulzberger, M. B., and Baer, R. L. (1948). 1948 Year Book of Dermato$\log y$, p. 7. Year Book Publishers, Chicago.

Suskind, R. R., Meister, M. M., Echeen, S. R., and Rebello, D. J. A. (1963). Arch. Derm., 88, 117.

Sutton, R. L. (1956). Diseases of the Skin, p. 885. Kimpton, London.

Wilkinson, D. S. (1962). Trans. St fohn's Hosp. derm. Soc. (Lond.), 48, 171 .

\title{
Further Serological Studies on the Rubella Syndrome
}

\author{
J. A. DUDGEON,* M.C., M.D. ; N. R. BUTLER,* M.D., M.R.C.P., D.C.H. \\ STANLEY A. PLOTKIN, $\dagger$ M.D.
}

Brit. med. F., 1964, 2, 155-160

A number of protozoal, bacterial, and viral infections contracted in pregnancy may give rise to foetal damage which becomes manifest either by abortion, stillbirth, a chronic sublethal infection recognizable after birth, or by teratogenic effect. The exact nature of the risk of foetal damage following infection is hard to assess except in the case of rubella. This relationship was first noted by Gregg (1941) and later by Swan (1944), who drew attention to malformation of the eyes and hearing-organs after maternal rubella in the first trimester. The detailed prospective studies of Lundström $(1952,1962)$ in Sweden and Manson et al. (1960) in England provided the necessary data for evaluation of this risk. Apart from a slightly higher incidence of stillbirths and infant deaths, the main effects noted were cataracts, deafness, and congenital heart disease, particularly patent ductus arteriosus, microcephaly, and coexistent mental retardation. These defects, occurring either singly or in combination, are referred to collectively as the rubella syndrome. In Lundström's series 1,146 pregnant women exposed to rubella were studied. The incidence of the rubella syndrome was $11 \%, 11 \%$, and $8 \%$ for each of the first three months respectively, with an overall incidence of $10 \%$ for the first trimester. The figures of Manson et al. for the same stages of pregnancy were 15.6, 19.7, and $13.0 \%$, and an overall figure of $15.8 \%$ for the first trimester. The figures for the second trimester from these two series were $0.9 \%$ and $2.6 \%$ respectively. Other prospective studies quoted by Lundström (1962) have shown wide variation and generally higher figures. However, in the light of present knowledge figures of Lundström and Manson et al. have received general acceptance, and there is general agreement that the highest incidence is in the first trimester.

The teratogenic effect of rubella on the human foetus is the reason for studying this otherwise mild infectious disease. The recent discovery, by several groups in North America, that the virus could be grown in cell culture opened up a new approach to the study of rubella and of the mechanism producing foetal damage. The first point studied was the serological status of children with the rubella syndrome. It was shown by Plotkin et al. (1963) that 8 out of 11 such children aged 5 months to 10 years had neutralizing antibody titres to rubella virus-six in high titre, two in titres of 4-and three children had no demonstrable antibody. The question that naturally arose from these findings was whether this antibody represented residual maternal antibody or whether it was actively produced. There seemed to be no reason why maternal

* The Hospital for Sick Children, Great Ormond Street, London. † The Wistar Institute, Philadelphia, Pa.; formerly, Medical Registrar, The Hospital for Sick Children, Great Ormond Street, London. antibody should persist for a longer period in rubella than in any other virus disease in which antibody passively transferred across the placenta disappears during the first six months of life. These results suggested, therefore, that antibody had been actively produced and that the foetus exposed to rubellavirus antigen in utero is not rendered immunologically tolerant. These sera were tested for neutralizing antibody by means of the interference-inhibition test in vervet-monkey-kidney cells as described by Parkman et al. (1962). Recently McCarthy et al. (1963) described an alternative method of measuring rubella-neutralizing antibody in a continuous line of rabbitkidney cells, the RK-13 line, in which rubella virus produces a cytopathic effect. We have found this to be a more convenient and reliable method for antibody estimation, and the results here reported have been obtained by this method. The present study reports our findings on a number of children with the rubella syndrome compared with control groups. It was carried out with the object of determining whether the foetus exposed to rubella virus was capable of developing an active immune response to the infection occurring in foetal life.

\section{Material and Methods}

The cases under investigation were divided into two main groups. Group $A$ : the rubella group; children with the rubella syndrome and children exposed to intrauterine rubella infection. Group $B$ : the control group.

\section{Group A : The Rubella Group}

Series 1.-This consisted of 14 children with the rubella syndrome, whose ages ranged from 4 months to 10 years, from whom a single sample of serum was collected. Five of these children were included in our previous report on the rubella syndrome (Plotkin et al., 1963).

Series II.-From each of 17 children with the rubella syndrome and their mothers serum specimens were obtained concurrently. In this group the diagnosis of rubella syndrome was checked with the hospital records. A history of maternal rubella was forthcoming in every case ; contact rubella infection with a member of the family was reported in seven cases; none of the mothers was given gamma-globulin after exposure.

Series III.-These six children were exposed to maternal rubella in the first trimester, but were without clinical evidence of rubella syndrome when examined at 6 months of age. 


\section{Group B : The Control Group}

Series IV.-A series of 50 cord bloods from University College Hospital, London, were examined to provide baseline information regarding the antibody content of infants of the London female population of child-bearing age. A series of 25 cord bloods from Kampala, in Uganda, were also included to compare the immune status in the two communities.

Series $V$.-Thirty-five sera were examined from children aged 1 month to 10 years admitted to the Hospital for Sick Children for a variety of causes, such as asthma, blood disorders, metabolic studies, respiratory and genito-urirary-tract infections, and for various forms of surgery.

\section{Laboratory Investigations}

Collection of Sera.-All sera were stored uninactivated at $-20^{\circ}$ C. until required for use.

Cell Culture.-(a) RK-13 cells, a transformed line of rabbitkidney cells, were initially obtained from Dr. A. J. Beale, Glaxo Laboratories Ltd., and at the time were at the 120th passage. The cells were maintained as stock cultures in Roux bottles in medium 199 with $5 \%$ inactivated calf serum. Roux bottles were trypsinized every week, and from each bottle approximately 200 tubes, each containing 200,000 cells, were obtained for neutralization tests. Tubes were incubated stationary at $37^{\circ} \mathrm{C}$. until cell sheets were confluent. They were then put on to maintenance medium consisting of medium 199, additional sodium bicarbonate $(0.176 \%)$, and $1 \%$ calf serum, and were placed on a roller-drum at the same temperature until inoculated. (b) Primary vervet-monkey-kidney-cell cultures were prepared from a trypsinized cell suspension. Roller-tube cultures were seeded with 75,000 cell aggregates per tube in medium 199 with $4 \%$ inactivated calf serum. Tubes were fluid-changed at four days on to maintenance medium consisting of medium 199 with $0.088 \%$ sodium bicarbonate and $1 \%$ calf serum.

Virus Strains.-Two virus strains were adapted to RK-13 cells. The "Marshall" strain isolated by Plotkin et al. (1963) and the "West Point" strain kindly sent to us by Dr. Maurice
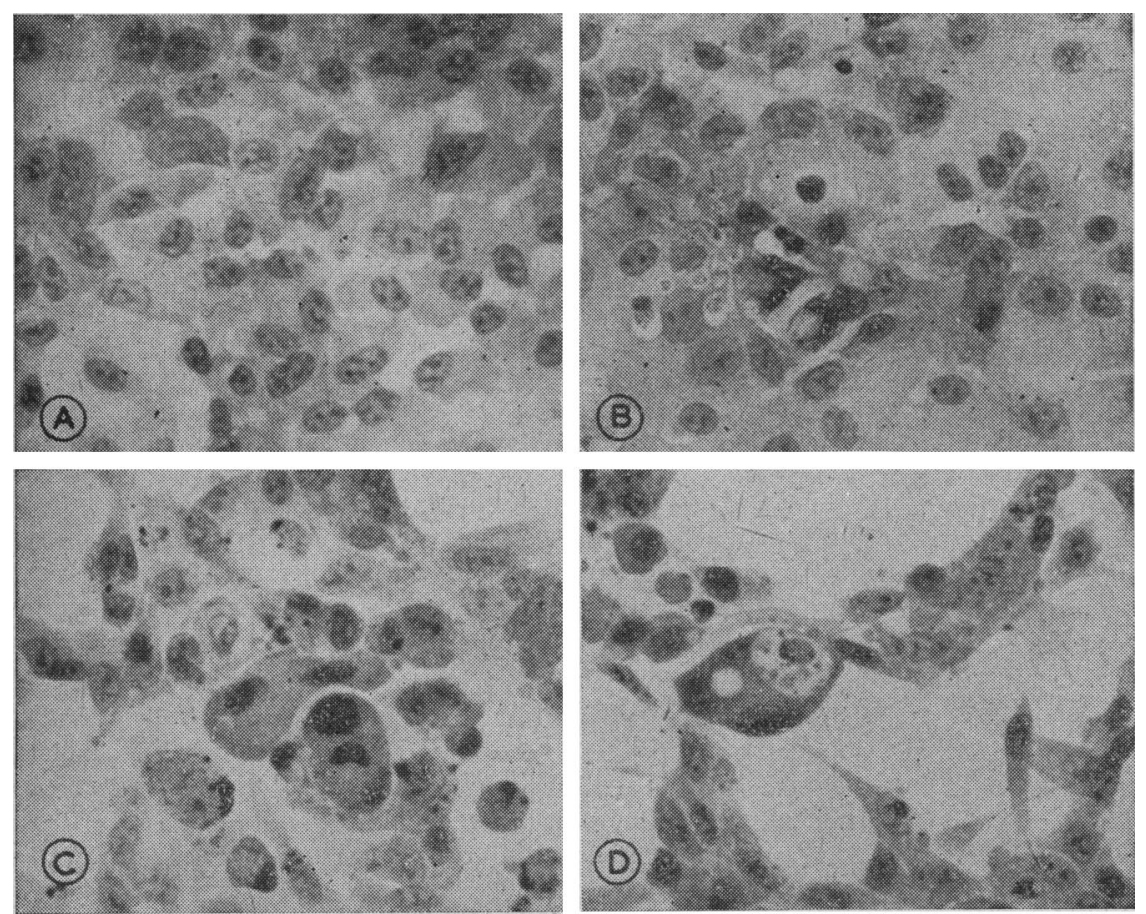

FIG. 1.-The cytopathic effect (C.P.E.) produced by rubella virus in RK-13 cells. (A) Normal uninoculated cell sheet. (B) C.P.E. at three days, showing early focal changes with cytoplasmic inclusion. (C) More advanced changes at seven days. (D) C.P.E. at 10 days, showing numerous gaps in the cell sheet with collections of cytoplasmic material.
Hilleman. Both strains had been passaged five times in primary vervet cells before adaptation and have since been passaged eight times in RK-13 cells. The West Point strain was used for the neutralization tests from a single pool of virus seed from the 8th RK-13 passage. This was stored at $-70^{\circ} \mathrm{C}$. and had an infectivity titre of $10^{4}$ TCID $_{50}$ per ml. as measured by the cytopathic effect.

Preparation of Hyperimmune Sera.-Antisera against the two strains were prepared by hyperimmunization of rabbits. Animals were immunized by an intravenous injection of $1 \mathrm{ml}$. of undiluted centrifuged tissue-culture fluid every week for three weeks. After the third injection three weeks was allowed to lapse before a booster injection was given. Animals were bled before and two weeks after the fourth inoculation.

Neutralization Test.-(a) In RK-13 cells. Neutralization tests were carried out using serial dilutions of serum and a constant dose of virus. Serial fourfold dilutions of serum were prepared in medium 199 to which were added aliquots of virus containing 100 TCID $_{50}$ determined by a previous titration. The virus seed was titrated in half-log steps, four tubes being used per dilution. Equal volumes of virus and serum dilution were held at $37^{\circ} \mathrm{C}$. for one hour and then placed in the refrigerator for one to two hours. An inoculum of $0.2 \mathrm{ml}$. was added to each of two tubes, which were then incubated at $35^{\circ} \mathrm{C}$. on a roller drum. Tubes were read by ordinary light microscopy, first at three days to determine whether cytopathic changes were showing in the virus control tubes and to make a preliminary reading, and finally at seven to eight days, when the final reading was taken. The end-point of the titration was taken as the highest dilution of serum showing partial protection of the cells from the serum-virus mixture. These are expressed as the final dilution of the serum in the serumvirus mixture. For the purposes of this investigation we have regarded only those sera showing no inhibition at a 1 in 4 dilution as seronegative or devoid of antibody as determined by the RK-13 test. Initially we found that the results of these titrations were more consistent if uninactivated serum was used, but later, when the virus was well adapted to RK-13 cells, these differences became less marked. The results of neutralization tests in RK-13 cells reported here were obtained with uninactivated sera. A few tests were also carried out incorporating normal untreated rabbit serum into the serum-virus mixtures as an activator as suggested by McCarthy et al. (1963), but we did not pursue this as we were able to obtain consistent results by the method described above. (b) A few comparative antibody titrations on rubella syndrome sera were carried out by the interference inhibition test described by Parkman et al. (1962) and exactly as outlined in our first communication (Plotkin et al., 1963). Echo 2 virus was used as the challenge virus.

Complement-fixation Tests.-A limited number of sera were tested for C.-F. antibodies to measles, adenovirus, and herpes viruses. Serial dilutions of serum were tested by overnight fixation against 4 units of viral antigens with $2 \frac{1}{2}$ doses of complement.

\section{Results}

\section{Cytopathic Changes in RK-cells}

The cytopathic changes in inoculated RK13 cultures appeared to be identical to those described by McCarthy et al. (1963) when examined by phase-contrast microscopy. However, after the third passage cytopathic changes could be seen with the ordinary light micro- 
scope. Uninoculated RK-13 cells showed a typical pattern of closely packed polygonal cells, each cell having numerous nucleoli ; occasional multinucleate cells and vacuolation were seen. The edge of the cell sheet showed numerous outgrowths with actively dividing cells (see Fig. 1). In rubella-infected cultures the first change noticed at about the third day was a rounding of cells at the edge of the culture, and at the same time scattered focal changes could be seen throughout the cell sheet. At first only a few cells were involved, but the cytopathic effect appeared to spread centrifugally, and by the seventh day as many as 6-10 foci could be seen per low-power field. Under the high-power field the earliest change seen was a lack of definition of the normal cell outline, followed by a loss of nucleoli, condensation, and fragmentation of the nuclear chromatin with retraction of the nucleus. At an early stage eosinophilic inclusion bodies surrounded by a clear halo could be seen in the cytoplasm (see Fig. 1B). By the fifth day virus-infected cultures showed many foci consisting of cells with large collections of granular eosinophilic material in the cytoplasm (see Fig. 1C). By the seventh or eighth day those focal areas had extended, celi necrosis was advanced, and gaps had appeared in the cell shcet. By the tenth day about $50 \%$ of the cell sheet had disappeared. Cytopathic changes seldom progressed to complete disintegration of the cell sheet. These changes were inhibited by the immune rubella antisera prepared against the two strains.

\section{Rubella Syndrome}

\section{Group A-Series I}

The neutralizing antibody titres on 14 children with rubella syndrome are shown in Table I together with the clinical type of congenital deformity. These sera were titrated in RK-13 and vervet cells on the same day. The titres show a uniform

TABLE I.-Rubella Syndromes. Maternal Rubella in First Trimester : Congenital Deformity (Single Serum Specimen (inly). Series I

\begin{tabular}{|c|c|c|c|c|c|}
\hline \multirow{2}{*}{$\begin{array}{l}\text { Case } \\
\text { No. }\end{array}$} & \multirow{2}{*}{ Patient } & \multirow{2}{*}{$\underset{\text { (Ygears) }}{\text { Age }}$} & \multirow{2}{*}{$\begin{array}{l}\text { Congenital } \\
\text { Defects }\end{array}$} & \multicolumn{2}{|c|}{$\begin{array}{c}\text { Neutralizing Àntibody } \\
\text { Titre }\end{array}$} \\
\hline & & & & MKC & RKC \\
\hline $\begin{array}{l}62 / 209 \\
63 / 97 \\
63 / 187 \\
63 / 43 \\
63 / 91 \\
62 / 275 \\
63 / 171 \\
63 / 164 \\
63 / 119 \\
63 / 155 \\
63 / 144 \\
63 / 152 \\
63 / 103 \\
63 / 110\end{array}$ & $\begin{array}{l}\text { M.H. } \\
\text { *.C. } \\
\text { S.S. } \\
\text { A.M. } \\
\text { N.A. } \\
\text { S.W. } \\
\text { *D.H. } \\
\text { *O'C } \\
\text { J.R. } \\
\text { A.G. } \\
\text { G.P.D. } \\
\text { E.F. } \\
\text { *M.W. } \\
\text { *S.J. }\end{array}$ & $\begin{array}{l}4 / 12 \\
11 / 12 \\
12 / 12 \\
16 / 12 \\
19 / 12 \\
18 / 12 \\
2 \\
4 \\
4 \\
6 \\
10 \\
10 \\
10 \\
11\end{array}$ & 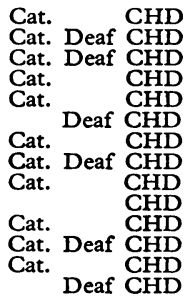 & $\begin{array}{r}64 \\
4 \\
\mathrm{nt} \\
64 \\
<4 \\
4 \\
16 \\
64 \\
<4 \\
64 \\
128 \\
128 \\
256 \\
256\end{array}$ & $\begin{array}{r}64 \\
4 \\
256 \\
128 \\
<4 \\
<4 \\
256 \\
64 \\
<4 \\
128 \\
256 \\
256 \\
128 \\
256\end{array}$ \\
\hline
\end{tabular}

*Sera tested in 1963. nt $=$ not tested (insufficient serum). Cat. = cataracts. $\mathrm{CHD}=$ congenital heart disease.

pattern and are similar to the cases of rubella syndrome in our first series (Plotkin et al., 1963). Of the 13 patients over the age of 6 months, nine had neutralizing antibody with titres of 64 or greater, one had a titre of 4 , and three had no detectable antibody at a $1: 4$ dilution, the lowest dilution tested. These three sera have been retested on several occasions with the same results.

\section{Group A-Series II. Mothers and Children with Rubella Syndrome}

The titres on 17 patients with the rubella syndrome and their mothers are shown in Table II. Fifteen of these had antibody levels ranging from 64 to 256 in both mother and child ; in seven the child's titre was higher than in the mother. One child (S.K.) was seen on two occasions. The first at 2 months when he was admitted for ligation of a patent ductus and the second at 15 months when he attended for a follow-up; on this second occasion blood was collected from the mother as well. All three specimens were titrated on the same day and it can be seen that there has been no diminution, even a twofold increase during this period. Two children had no detectable antibody. One child who was reported to be deaf (T.P., aged 5 months) had no detectable antibody and further investigation is required. A second child (Y.G., aged 6 months) had no antibody and the mother had a titre of 4 , so this

TABLE II.-Rubella Syndromes. Maternal Rubella in First Trimester: Congenital Deformity (Paired Sera from Mother and Child). Series II

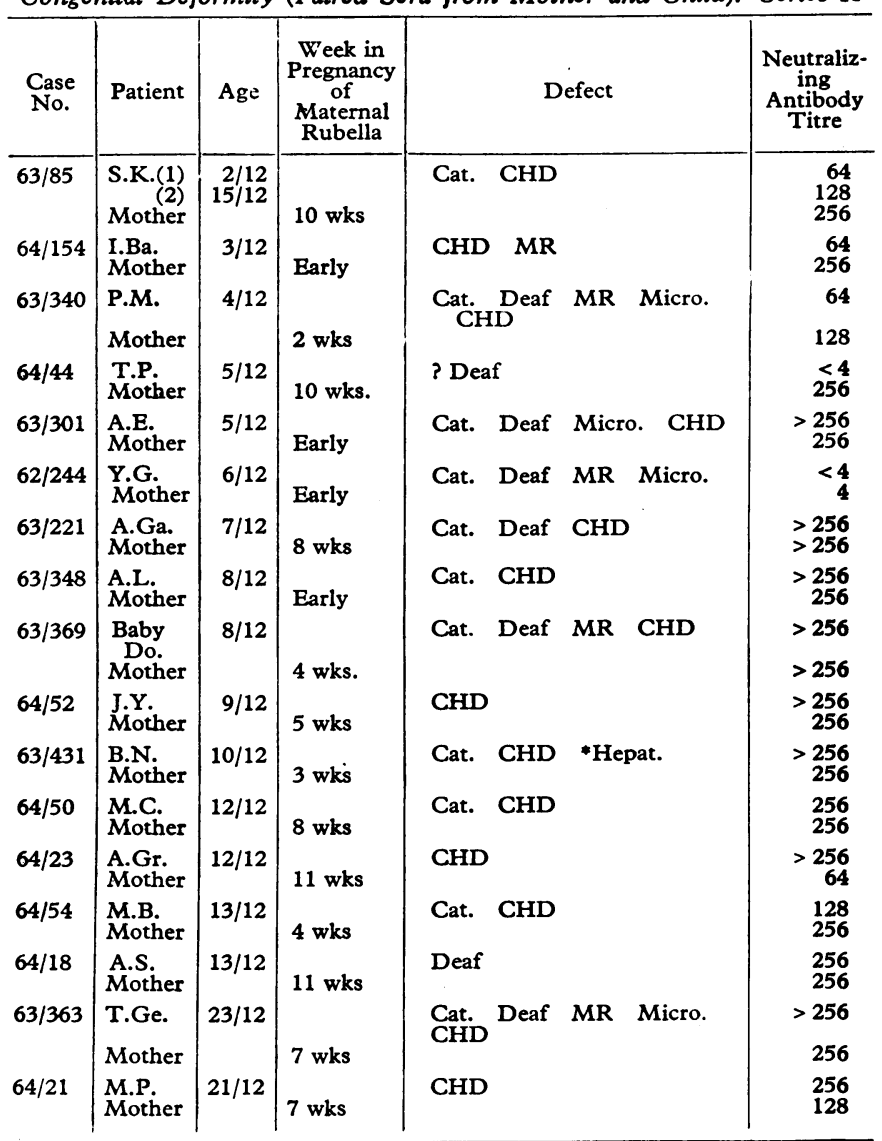

Cat. $=$ cataracts. CHD $=$ congenital heart disease. Micro. $=$ microcephaly. $M R=$ mental retardation. ${ }^{*}$ Hepatomegaly and neonatal purpura.

TABLE III.-Rubella Syndromes. Maternal Rubella in First Trimester : Congenital Deformity. Complement-fixing Antibody Titres to Other Viral Antigens

\begin{tabular}{|c|c|c|c|c|c|}
\hline \multirow{2}{*}{$\begin{array}{l}\text { Case } \\
\text { No. }\end{array}$} & \multirow{2}{*}{ Patient } & \multirow{2}{*}{ Age } & \multicolumn{3}{|c|}{ C.F. Antibody Titre } \\
\hline & & & Measles & Adenovirus & Herpes \\
\hline $63 / 85$ & $\begin{array}{l}\text { Mother } \\
\text { S.K. (1) } \\
\text { (2) }\end{array}$ & $\begin{array}{r}2 / 12 \\
15 / 12\end{array}$ & $\begin{array}{r}160 \\
10 \\
80\end{array}$ & $\begin{array}{l}60 \\
10 \\
10\end{array}$ & $\begin{array}{r}160 \\
10 \\
60\end{array}$ \\
\hline $63 / 369$ & $\begin{array}{l}\text { Mother } \\
\text { Baby Do. }\end{array}$ & $8 / 12$ & $\begin{array}{r}160 \\
20\end{array}$ & $\begin{array}{r}160 \\
10\end{array}$ & $\begin{array}{r}240 \\
10\end{array}$ \\
\hline $64 / 52$ & $\begin{array}{l}\text { Mother } \\
\text { J.Y. }\end{array}$ & $9 / 12$ & $\begin{array}{r}160 \\
10\end{array}$ & $\begin{array}{r}160 \\
10\end{array}$ & $\begin{array}{r}160 \\
10\end{array}$ \\
\hline $64 / 23$ & $\begin{array}{c}\text { Mother } \\
\text { A.Gr. }\end{array}$ & $12 / 12$ & $\begin{array}{l}160 \\
A C\end{array}$ & $\begin{array}{r}40 \\
\mathrm{AC}\end{array}$ & $\begin{array}{l}160 \\
\mathrm{AC}\end{array}$ \\
\hline $64 / 18$ & $\begin{array}{c}\text { Mother } \\
\text { A.S. }\end{array}$ & $12 / 12$ & $\begin{array}{r}320 \\
10\end{array}$ & $\begin{array}{r}120 \\
10\end{array}$ & $\begin{array}{r}320 \\
10\end{array}$ \\
\hline $64 / 56$ & $\begin{array}{c}\text { Mother } \\
\text { M.C. }\end{array}$ & $12 / 12$ & $\begin{array}{r}160 \\
10\end{array}$ & $\begin{array}{l}80 \\
10\end{array}$ & $\begin{array}{r}160 \\
10\end{array}$ \\
\hline $64 / 54$ & $\begin{array}{c}\text { Mother } \\
\text { M.B. }\end{array}$ & $13 / 12$ & $\begin{array}{l}80 \\
10\end{array}$ & $\begin{array}{l}60 \\
10\end{array}$ & $\begin{array}{r}320 \\
10\end{array}$ \\
\hline $64 / 21$ & $\begin{array}{c}\text { Mother } \\
\text { M.P. }\end{array}$ & $19 / 12$ & $\begin{array}{r}120 \\
10\end{array}$ & $\begin{array}{l}10 \\
60\end{array}$ & $\begin{array}{r}160 \\
10\end{array}$ \\
\hline
\end{tabular}

*AC = Anticomplementary. 
raises the question whether the maternal illness was in fact rubella. With such a recent infection one would expect the mother's antibody titre to be higher. Both patients have been left in this series because the criteria for inclusion were fulfilled-that is, maternal rubella diagnosed by a physician and a deformity in the child consistent with the rubella syndrome.

These results pointed to persistence of rubella antibody, and in order to determine whether other viral antibodies behaved in the same way sera from eight of these children and their mothers were measured for complement-fixing antibodies to measles, adenovirus, and herpes. The results are shown in Table III. In most cases the expected decline of passively transferred maternal antibody has occurred. In one or two instances (Case 64/21 M.P.) an increase has occurred in adenovirus antibody, and in Case 63/85 S.K. there has been an increase in both measles and herpes antibodies. These results indicate that maternal antibody to viruses other than rubella decline in the usual way in children with the rubella syndrome.

\section{Group A-Series III}

Six children with no gross abnormality were also tested. The results are shown in Table IV. Of these, four showed

Table IV.-Maternal Rubella: No Deformity in Child (Paired Sera

\begin{tabular}{|c|c|c|c|c|c|}
\hline $\begin{array}{l}\text { Case } \\
\text { No. }\end{array}$ & $\begin{array}{l}\text { Patient } \\
\text { and } \\
\text { Mother }\end{array}$ & $\begin{array}{l}\text { Age } \\
\text { of } \\
\text { Child }\end{array}$ & $\begin{array}{c}\text { Week in } \\
\text { Pregnancy } \\
\text { of } \\
\text { Maternal } \\
\text { Rubella }\end{array}$ & Deformity of Child & $\begin{array}{l}\text { Reciprocal of } \\
\text { Neutralizing } \\
\text { Antibody } \\
\text { Titre } \\
\text { Tested in } \\
\text { RK13 Cells }\end{array}$ \\
\hline \multirow[t]{2}{*}{$63 / 404$} & Baby Q. & $3 / 52$ & & B.wt. 3 lb. $6 \mathrm{oz}$. & 256 \\
\hline & Mother & & 10 wks & & 256 \\
\hline $63 / 182$ & $\begin{array}{c}\text { Baby N.M. } \\
\text { Mother }\end{array}$ & $4 / 12$ & 6 wks & Failure to thrive & $\begin{array}{r}4 \\
128\end{array}$ \\
\hline $63 / 367$ & Baby F. & $9 / 12$ & $12 \mathrm{wks}$ & None detected & $\begin{array}{l}256 \\
256\end{array}$ \\
\hline $63 / 385$ & $\begin{array}{l}\text { Baby L. } \\
\text { Mother }\end{array}$ & $10 / 12$ & 12 wks & None detected & $\begin{array}{l}>256 \\
>256\end{array}$ \\
\hline 63/359 & $\begin{array}{l}\text { Baby } T \text {. } \\
\text { Mother }\end{array}$ & $10 / 12$ & $10 \mathrm{wks}$ & None detected & $\begin{array}{r}4 \\
128\end{array}$ \\
\hline $63 / 398$ & $\begin{array}{l}\text { Baby Ta. } \\
\text { Mother }\end{array}$ & $11 / 12$ & $14 \mathrm{wks}$ & ? retarded & $\begin{array}{r}256 \\
>256\end{array}$ \\
\hline
\end{tabular}

similar titres to the group with congenital deformities; one of these children had a low birth weight and another was physically retarded, but as they are all under 1 year of age it is not possible to rule out minor abnormalities such as unilateral nerve-deafness. Two had low antibody levels with titres of 4 , one of whom was reported as a failure to thrive.

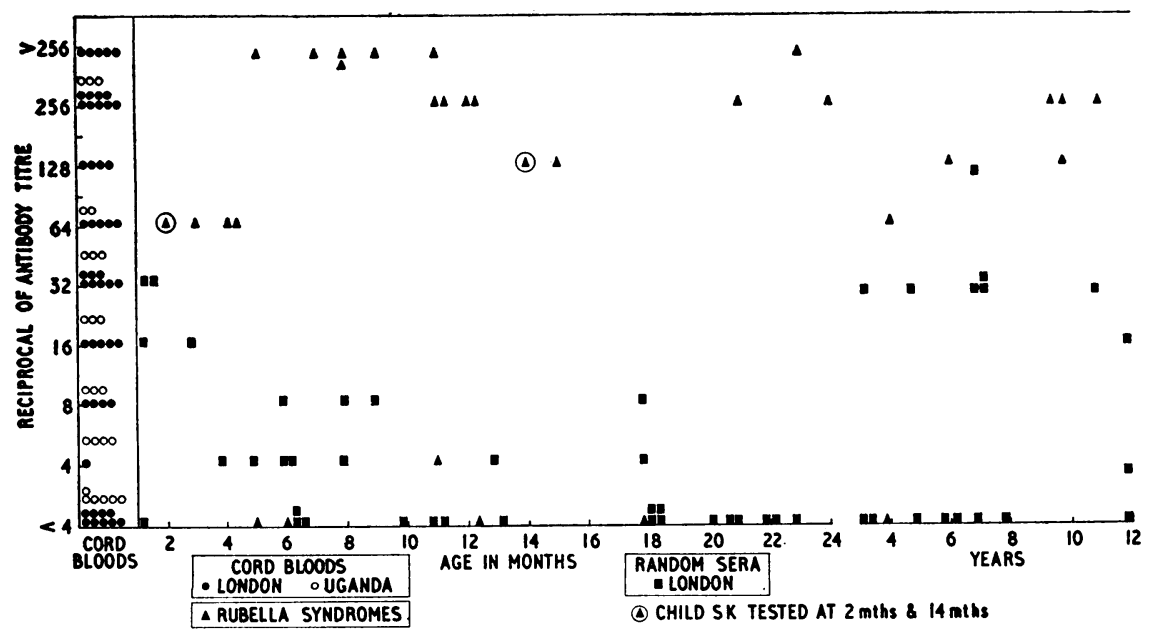

Fig. 2.-Rubella syndromes, cord bloods, and random sera. Rubella-neutralizing antibody

\section{Group B-Controls}

Series $I V$. - The results of the cord bloods and the random sera from non-rubella-syndrome children are shown in Table

TABLE V.-Rubella Neutralization Tests on Cord Bloods

\begin{tabular}{|c|c|c|c|c|c|c|c|c|}
\hline \multirow{2}{*}{ Group } & \multirow{2}{*}{$\begin{array}{l}\text { No. } \\
\text { Tested }\end{array}$} & \multicolumn{6}{|c|}{$\begin{array}{l}\text { No. of Sera with Antibody } \\
\text { at each Dilution }\end{array}$} & \multirow{2}{*}{$\begin{array}{c}\text { Pro- } \\
\text { portion } \\
\text { Sero- } \\
\text { negative }\end{array}$} \\
\hline & & $<4$ & 4 & $8-16$ & $32-64$ & $128-256$ & $>256$ & \\
\hline $\begin{array}{c}\text { Cord bloods .. } \\
\text { (London) }\end{array}$ & 50 & 9 & 1 & 9 & 13 & 13 & 5 & $9 / 50$ \\
\hline $\begin{array}{l}\text { Cord bloods ... } \\
\text { (Uganda) }\end{array}$ & 25 & 6 & 4 & 3 & 8 & 4 & - & $6 / 25$ \\
\hline
\end{tabular}

V. Out of 50 cord bloods from a London obstetric hospital 40 had antibody titres of 8 or more. There appeared to be a more marked scatter in antibody titre than is encountered in convalescent sera, probably due to the length of time that has elapsed since infection. Of the remainder, one had a titre of 4 and nine $(18 \%)$ were devoid of antibody or sero-negative ; these presumably represent the susceptible population. The corresponding figures on the sera from Uganda were six out of $25(24 \%)$ seronegative.

Series $V$.-The results on the random sera from hospital admissions other than the rubella syndrome show a progressive decline in inherited rubella antibody during the first year of life. These are shown in Fig. 2, and for comparison the titres of the cord bloods (Group B) and rubella syndrome sera (Group A-Series I and II) are also shown. The difference is striking.

In the random series aged 1 month to 2 years, nine sera were devoid of antibody, and the remainder, other than two from infants aged 1 month, had low levels of antibody of 4 to 8 . It is only in the group aged 5-12 years that children with higher levels of antibody were encountered.

\section{Discussion}

At the beginning of these studies the question was asked, "Are children born after intrauterine rubella infection capable of producing antibodies to the virus, or are they immunologically paralysed owing to early contact with the antigen ?" In our previous paper it was shown that they do produce antibodies (Plotkin et al., 1963). Indeed, rather than being immunologically paralysed, most of the children in this present series were at least as good antibody-producers as their mothers, and in some cases even better.

The next question posed was, Are the antibodies produced by the intrauterine stimulus or are they acquired in the usual way subsequent to rubella infection after birth ? The serological determinations reported here show that children with rubella syndrome have antibody titres consistently higher than their normal cohorts, particularly during the ages from 6 months to 5 years, when normal children are largely seronegative. On the other hand, in the few patients that were examined the titres of C.-F. antibodies to measles, adenovirus, and herpes virus were with few exceptions at the very low levels that were expected for passively transferred antibody. Thus the answer to the second question appears to be that the rubella antibodies are a response to intrauterine infection. It is useful to note that exactly comparable results have been obtained by Weller and his colleagues (1964) in the United States.

A third question, which cannot yet be answered, is, Does the active antibody response 
occur at the time of infection in the first trimester, later in the pregnancy, or shortly after birth ? This last question raises still another one of the greatest theoretical interest. How early can the human foetus respond with antibody ? In children with the rubella syndrome a foreign antigen, the virus, invades the foetus during the earliest stages (12 weeks) of pregnancy. It may be that at this stage the foetus begins to develop antibodies, but at present there is no evidence to support this hypothesis. An alternative explanation is that the virus persists in the foetus until the development of immunological competence later in ontogenesis. Credence is lent to this possibility by the observations of several workers that rubella virus can in fact be recovered from an aborted foetus long after the maternal infection-in one case 18 weeks after the maternal illness and in the 24th week of pregnancy (Porterfield, 1964, personal communication).

On the other hand, present thinking concerning the development of immunological competence in man emphasizes the considerable abilities of the human foetus rather than its specific deficiencies. As Smith and Eitzman (1964) point out, " immunity, like all developmental processes, must not be measured to adult norms. At each stage of ontogeny the mechanisms which have evolved should be judged by their appropriateness in dealing with the threats to survival peculiar to the epoch rather than those of full maturity."

Unquestionably, infants during the first two months of life respond relatively poorly to some antigens (Osborn et al., 1952 ; Plotkin et al., 1959), but definite serological responses to perinatal virus infections, though not comparable to those occurring later in life, have been demonstrated in premature and full-term infants infected with a number of enteroviruses (Plotkin et al., 1959; Eichenwald and Kotsevalov, 1960; Steigman and Lipton, 1960 ; Pagano et al., 1962). Infants infected with Escherichia coli (Stulberg et al., 1956) as well as those given salmonella vaccines (Smith and Eitzman, 1964) or diphtheria toxoid (Dancis et al., 1953) may also produce antibodies.

Much less is known, of course, concerning immunological competence before birth. Although plasma cells, the producers of $7 \mathrm{~S}$ gamma-globulin, are absent in the normal infant before 6 weeks of age (Bridges et al., 1959), they have been demonstrated in an infected foetus as early as $4 \frac{1}{2}$ months of gestation (Benirschke and Bourne, 1958). Silverstein and Lukes (1962) found plasma cells in foetuses aborted at 29 weeks of gestation after infection with Toxoplasma or Treponema. They allude to earlier pathological studies showing that inflammatory response to syphilitic infection does not occur before 5 months of gestation. In an important experimental study Silverstein et al. (1963) observed the serological responses of foetal lambs to a variety of inoculated substances and found what they called a "hierarchy" of antigens. The youngest foetus tested, which had developed to 66-70 days of a 150-day gestation, responded to some of the inoculated antigens. For example, during foetal life the lamb produced antibodies very well to ferritin, less well to ovalbumin, and not at all to diphtheria toxoid. In addition, Eichenwald and Shinefield (1963) have identified foetal toxoplasma antibody in the $19 \mathrm{~S}$ fraction of foetal serum as early as the 28th week of gestation. These antibodies were presumably not of maternal origin because $19 \mathrm{~S}$ globulin cannot normally cross the placenta. Uhr and Finkelstein (1963) have shown that in guinea-pigs antigenic stimuli resulting in $19 S$ antibody do not cause persistence of antibody, but rather that immunological memory develops only when $7 \mathrm{~S}$ antibodies are stimulated. It is possible that in order to produce persistent antibodies the rubella virus must multiply in the foetus until the ability to produce $7 \mathrm{~S}$ antibodies develops.

Thus, from all these data and our own with respect to rubella it appears that, as yet, no lower limit can be set to the immunological competence of the human foetus, and there seems to be no reason why, therefore, the foetus cannot develop antibody against rubella. Although $7 \mathrm{~S}$ antibody may not be produced before the fifth month, it is possible that $19 \mathrm{~S}$ antibody can be produced earlier. Immunological maturity is clearly dependent upon the potency of the antigenic stimulus, which in the case of rubella-virus infection of the foetus must be considerable.

The five rubella syndrome cases shown in Tables I and II in which the titre of rubella antibody was less than 4 are interesting, and can be explained in several ways.

(1) The initial maternal infections were not rubella but were caused by another virus. This could be the explanation for the child (Y.G., Series II) with no antibody whose mother had a titre of only 1 in 4 .

(2) The rubella infection was short in duration and the resulting antigenic stimulus insufficient for antibody production.

(3) Antibodies were present but have since disappeared.

(4) The children whose sera were negative were tolerant to rubella antigen. It would be useful to check these two latter possibilities by means of a skin test antigen, if a suitable rubella antigen could be developed, in order to determine whether the antibody response is negative, normal, or accelerated.

It seems unlikely that tolerance would develop in such a small proportion of rubella-infected foetuses, but at present little is known of the factors that determine whether a foetus responds to an antigenic stimulus with normal reactivity or tolerance. Age and the nature of the antigen are probably both important determining factors, as Weiss and Wells (1957) have shown in experimental studies on tuberculin sensitivity in foetal guinea-pigs. The fact that immunological tolerance does not occur, or at most occurs rarely, in the rubella syndrome raises questions about the existence of tolerance in the human foetus. The development of tolerance, as the development of immunological competence discussed above, undoubtedly depends on the antigens employed and the species involved (Ebert and DeLanney, 1960; Billingham, 1964). The best established examples of tolerance in the human are to its own tissues and in twins who are chimeras with respect to blood-cell antigens (Woodruff and Lennox, 1959). Partial tolerance has also been found in infants grafted with their mother's skin and in infants given exchange transfusions and then grafted with skin from the blood-donors (Woodruff, 1957 ; Peer, 1957 ; Fowler et al., 1960). Tolerance to viruses, however, appears difficult to obtain. The only well-founded instance seems to be that of lymphocytic choriomeningitis injected into newborn mice (Traub, 1960 ; Weigand and Hotchin, 1961). In the human premature and full-term newborn infant infection with attenuated poliovirus fails to produce tolerance even when no antibody is stimulated and reinfection later in life has resulted in a normal serological response (Pagano et al., 1960, 1962).

The lack of tolerance in rubella syndrome cases can be explained on the grounds that the antigen is subcellular. It would appear difficult, however, to reconcile these findings with the clonal selection theory of immunity (Burnet, 1959), unless the invasion of rubella virus is thought insufficient to remove all cells capable of producing rubella antibody.

\section{Summary}

Serological tests are reported on 31 children with congenital defects following maternal rubella in the first trimester. Neutralizing antibodies were titrated in the RK-13 transformed line of cells, which was found to be a more convenient system of measuring antibody than by the interference-inhibition test in vervet cells. It was found that children with the rubella syndrome have neutralizing antibody consistently higher than their normal cohorts. Of the 31 children, 25 were aged 6 months to 10 years, and of these only three were seronegative. Tests were also carried out on 17 of these patients and their mothers; fifteen of these had antibody levels ranging from 64 to 256 in both mother and child ; in seven the child's titre was higher than in the mother. Of the six children born after maternal rubella but with no gross abnormalities, four showed similar titres to the group with congenital defects. It is concluded that intrauterine infection with rubella virus does 
not lead to immunological tolerance but is followed by persistence of virus, with subsequent development of active immunity probably by the foetus or early in post-natal life. These findings suggest that as yet the lower limit for immunological competence on the part of the foetus has yet to be determined.

We are extremely grateful to our colleagues at the Hospital for Sick Children, Great Ormond Street, in particular to Dr. R. E. Bonham-Carter, and also to many consultant paediatricians throughout the country, especially Dr. R. J. K. Brown, Queen Elizabeth Hospital for Children, Hackney, who have referred patients to us. We are also grateful to the obstetric units at University College Hospital, London, and Makerere College, Kampala, for provision of cord bloods.

\section{REFERENCES}

Benirschke, K., and Bourne, G. C. (1958). Obstet. and Gynec., 12, 495 Billingham, R. E. (1964). Trans. Coll. Phycns Philad., 31, 187. Bridges, R. A., Condie, R. M., Zak, S. J., and Good, R. A. (1959). F. Lab. clin. Med., 53, 331.

Burnet, F. M. (1959). Brit. med. F., 2, 645.

Danc1s, J., Osborn, J. J., and Kunz, H. W. (1953). Pediatrics, 12, 151.

Ebert, J. D., and Delanney, L. E. (1960). Nat. Cancer Inst. Monogr. No $2,73$.

Eichenwald, H. F., and Kotsevalov, O. (1960). Pediatrics, 25, 829

- and Shinefield, H. R. (1963). F. Pediat., 63, 870.

Fowler. R., Schubert, W. K., and West, C. D. (1960). Ann. N.Y. Acad. Sct., 87,403 .
Gregg, N. McA. (1941). Trans. ophthal. Soc. Aust., 3, 35

Lundström, R. (1952). Acta Paediat. (Uppsala), 41, 583.

- (1962). Ibid., 51, Suppl. No. 133.

McCarthy, K., Taylor-Robinson, C. H., and Pillinger, S. E. (1963). Lancet, 2, 593.

Manson, M. M., Logan, W. P. D., and Loy, R. M. (1960). Reports on Public Health and Medical Subjects No. 101. H.M.S.O., London.

Osborn, J. J., Dancis, J., and Julia, J. F. (1952). Pediatrics, 9, 736.

Pagano, J. S., Plotkin, S. A., Cornely, D., Leuterer, W., and Koprowski, H. (1962). Ibid., 29, 794.

- and Koprowski, H. (1960). Lancet, 1, 1224.

Parkman, P. D., Buescher, E. L., and Artenstein, M. S. (1962). Proc. Soc. exp. Biol. (N.Y.), 111, 225.

Peer, L. A. (1957). Transpl. Bull., 4, 109.

Plotkin, S. A., Dudgeon, J. A., and Ramsay, A. M. (1963). Brit. med. 7., 2, 1296.

Koprowski, H., and Stokes, J. (1959). Pediatrics, 23, 1041.

Porterfield, J. S. (1964). Personal communication.

Silverstein, A. M., and Lukes, R. J. (1962). Lab. Invest., 11, 918. Uhr, J. W., Kramer, K. L., and Lukes, R. J. (1963). F. exp. Med., $117,799$.

Smith, R. T., and Eitzman, D. V. (1964). Pediatrics, 33, 163

Steigman, A. J., and Lipton, M. M. (1960). Amer. F. Dis. Child., 100, 537.

Stulberg, C. S., Zuelzer, W. W., and Page, R. H. (1956). F. Immunol., 76, 281 .

Swan, Ch. (1944). 7. Path. Bact., 56, 289

Traub, E. (1960). Arch. ges. Virusforsch., 10, 303.

Uhr, J. W., and Finkelstein, M. S. (1963). f. exp. Med., 117, 457.

Weigand, H., and Hotchin, J. (1961). 7. Immunol., 86, 401

Weiss, D. W., and Wells, A. Q. (1957). Nature (Lond.) 179, 978.

Weller, T. H., Alford, C. A., and Neva, F. A. (1964). New Engl. 7. Med., 270, 1039.

Woodruff, M. F. A. (1957). Transpl. Bull., 4, 26.

- and Lennox, B. (1959). Lancet, 2, 476.

\title{
A Five-year Follow-up of 100 Neurotic Out-patients
}

\author{
R. GIEL, ${ }^{*}$ M.D. ; R. S. KNOX,* M.D. ; G. M. CARSTAIRS,* M.D., F.R.C.P.ED., D.P.M.
}

Brit. med. F., 1964, 2, 160-163

The course and duration of the neuroses-their natural history -merits attention so that the effects and effectiveness of different treatments can be assessed. According to Landis (1938), $66 \%$ of hospitalized neurotics in the United States in 1933 and $68 \%$ in New York in 1914 were adjudged subjectively by their clinician to be recovered or improved at the time of their discharge within one year of admission. He thought that, though recovery might not strictly be termed spontaneous in these cases, nevertheless any therapeutic method must show better rates than this before being acclaimed. Eysenck (1952) reviewed a number of studies which showed that within two years of the onset of their illness two-thirds will have improved with or without treatment. Shepherd and Gruenberg (1957) compared prevalence and incidence rates for neurosis in the Health Insurance Plan of Greater New York and concluded that the average duration was between onc and two years. They state: "In the mass, neuroses must have a limited course even if untreated." Hastings (1958) found a good outcome in $46 \%$ of 731 hospitalized neurotics 6 to 12 years later. Wallace and Whyte (1959) demonstrated a remission rate of $66 \%$ in 49 neurotics who had been on the waiting-list for out-patient psychotherapy for three years or more. They also found that "any recovery which had taken place had done so in the first three years."

Ernst (1959) reported an unusually long-term follow-up study in Zurich in which he ascertained the outcome of 126 neurotic patients (excluding cases presenting antisocial characteristics or personality disorders) after an interval of from 18 to 42 years (mean, 24 years). At the time of re-examination $25 \%$ of the patients were adjudged to be unimproved or worse. Syndromes

* Medical Research Council Unit for Research on the Epidemiology of Psychiatric Illness, Depariment of Psychological Medicine, University of Edinburgh. in which anxiety, hypochondriasis, or neurasthenia played a prominent part showed little tendency to improve whereas hysterical and depressive, and psychosomatic, syndromes tended to show improvement, with intermittent recurrence during episodes of stress. A quarter of these patients had five or more psychotherapeutic interviews, but their outcome was not demonstrably different from that of the remainder. Miles et al. (1951) and Pollitt (1960) indicated that most studies of neurosis lack diagnostic precision and fail to stipulate criteria for judging outcome; also that in most cases the follow-up of patients has been far from complete. Consequently, most follow-up studies of neuroses have been of limited scientific value.

How far studies of patients can be regarded as indicating the "natural history" of illnesses is also a moot point. However, one or two consultations with a psychiatrist certainly do not permit any formal treatment programme to be implemented, and, as Strömgren (1961) has pointed out, in our society some degree of medical intervention has to be accepted as part of the natural course of illness.

\section{Method}

Among 1,027 new consultations at the out-patient clinics of the Department of Psychological Medicine of the Royal Infirmary of Edinburgh during 1957 and 1958 there were 212 cases of neurosis. From these a random sample of 100 patients aged between 15 and 55 years was followed up five years later. The random sample contained 42 men and 58 women, which corresponded closely to the sex distribution ( $43 \%$ men) in the total 212 cases.

Since not every case note bore a definite diagnosis, cases of neurosis were identified by the exclusion of all patients in 